\section{Hitting Hsp90 where it hurts}

\section{By Kai-Jye Lou, Staff Writer}

Researchers at the University of Massachusetts Medical School have synthesized a class of targeted molecules called gamitrinibs that selectively inhibit Hsp90 in tumor mitochondria, the organelle where Hsp90 exerts many of its cancer-promoting effects. The compounds could have an advantage over the plethora of Hsp90 inhibitors in the clinic that exert their effects in the cytosol. ${ }^{1}$

Heat shock protein 90 (HSP90AA1; Hsp90) is a chaperone that facilitates proper protein folding in multiple signaling pathways, including those that drive tumor development and progression. In tumor cell mitochondria, the protein can preserve organelle integrity and

\section{"The gamitrinibs are} cytotoxic. Rather than taking two days, the gamitrinibs kill tumor cells in one hour." - Dario Altieri,

University of Massachusetts Medical School amino)-17-demethoxygeldanamycin (17-AAG)-derived benzoquinone ansamycin backbone to a mitochondrial-targeting moiety. Molecular dynamic simulation studies suggested that the 17-AAG portion of gamitrinibs antagonize the ATPase pocket on Hsp90.

17-AAG from Bristol-Myers Squibb Co. is an ansamycin-based Hsp90 inhibitor known as tanespimycin. It is in Phase III testing for multiple myeloma (MM).

In xenograft mouse models of human leukemia, breast cancer and lung cancer, a gamitrinib analog lowered tumor proliferation, whereas 17-AAG did not. The gamitrinib also showed activity across a panel of 12 cancer cell lines with a mean $\mathrm{IC}_{50}$ of $10.9 \mu \mathrm{M}$. In contrast, 17-AAG showed lower efficacy in each cell line and had $\mathrm{IC}_{50}$ values greater than $200 \mu \mathrm{M}$ in 8 of 12 cell lines.

Concentrations of the gamitrinibs that killed tumor cells did not induce cell death in a panel of normal cells, and organs isolated from gamitrinib-treated mice were histologically similar to those from vehicle-treated controls.

Indeed, gamitrinibs selectively accumulated in tumor cell mitochondria, disrupted their integrity and caused cell death by mitochondriainduced apoptosis. The compounds showed negligible activity against cytosolic Hsp90.

"The most significant potential benefit of the gamitrinibs would be an improvement in the therapeutic index over the currently availprevent the initiation of cell death. ${ }^{2}$ By contrast, in most normal cells, Hsp90 is expressed in the cytosol, where it protects the cells from environmental stressors like heat and hypoxia.

Because tumor cells can exploit the protective properties of mitochondrial Hsp90, Dario Altieri and collaborators set out to synthesize therapeutics targeted to subcellular compartments-specifically, mitochondria. "We coupled a known Hsp90 inhibitor backbone from 17-AAG with molecules that are known to target cargo to mitochondria," he told SciBX. Altieri is chair of the Department of Cancer Biology at UMass Medical.

The resulting compounds, published in The Journal of Clinical Investigation, were geldanamycin mitochondrial matrix inhibitors (gamitrinibs). The compounds were synthesized by linking a 17-(allylable ansamycins" like 17-AAG, said Luke Whitesell, a senior research scientist at the Whitehead Institute for Biomedical Research.

\section{The targeted advantage}

At least eight Hsp90 inhibitors are in clinical development to treat cancer (see Table 1, “Hsp90 pipeline”). By comparison, Altieri thinks gamitrinibs have the potential for increased activity and lower toxicity.

"What we have seen is that the pool of Hsp90 in mitochondria escapes inhibition by conventional small molecule Hsp90 antagonists," he told SciBX. "What we wanted to do was show that the mitochondrial pool of Hsp90 is very important for tumor cell survival."

Table 1. Hsp90 pipeline. At least eight inhibitors of heat shock protein 90 (HSP90AA1; Hsp90) are in clinical development for various cancers.

\begin{tabular}{llll}
\hline Company & Product & Indication & Status \\
\hline Bristol-Myers Squibb Co. (NYSE:BMY) & Tanespimycin & Multiple myeloma (MM) and other cancers \\
\hline Infinity Pharmaceuticals Inc. (NASDAQ:INFI) & Retaspimycin & Gastrointestinal stromal tumors (GIST) and other cancers & Phase III (GIST) \\
\hline Biogen Idec Inc. (NASDAQ:BIIB) & BIIB021 & GIST & Phase II \\
\hline Vernalis plc (LSE:VER)/Novartis AG (NYSE:NVS; SIX:NOVN) & AUY922 & Cancer & Phase I/II \\
\hline Astex Therapeutics Ltd. & AT13387 & Cancer & Phase I \\
\hline Infinity & IPI-493 & Cancer & Phase I \\
\hline Kyowa Hakko Kirin Co. Ltd. (Tokyo:4151) & KW-2478 & Cancer & Phase I \\
\hline Synta Pharmaceuticals Corp. (NASDAQ:SNTA) & STA-9090 & Cancer & Phase I \\
\hline
\end{tabular}

Source: $\mathrm{BCIQ}$ : BioCentury Online Intelligence 


\section{TARGETS \& MECHANISMS}

Data in the JCI article showed that the nonorganelle-targeted Hsp90 inhibitors 17-AAG, IPI-504, BIIB021 and NVP-AUY922 primarily lowered cytosolic Hsp90 activity and did not disrupt mitochondrial integrity.

Altieri noted that such inhibitors typically induce a cytostatic phenotype in tumor cells. "These cells are not dead-they simply stop dividing for a while and only start to die after about two to three days," he said. "The gamitrinibs are cytotoxic. Rather than taking two days, the gamitrinibs kill tumor cells in one hour. They eliminate a very important mechanism for maintaining mitochondrial integrity in cancer cells."

IPI-504 from Infinity Pharmaceuticals Inc., an ansamycin also known as retaspimycin, is in Phase III testing to treat gastrointestinal stromal tumors (GIST). BIIB021, a purine-based analog from Biogen Idec Inc., is in Phase II testing to treat GIST. NVP-AUY922, a resorcinol-based Hsp90 inhibitor from Vernalis plc and Novartis AG, is in Phase I testing to treat solid tumors and hematological malignancies. All of the companies offered no comments about the UMass research.

Neil Thompson, SVP of biology at Astex Therapeutics Ltd., which is also developing an Hsp90 product, also noted that the Hsp90 inhibitors in the clinic prompt tumor cells to induce the action of Hsp70 (HSPA4), which can counter the inhibitor's activity. "All such compounds that I am aware of elicit this compensatory mechanism," he told SciBX. Like Hsp90, Hsp70 is a chaperone protein that promotes cell survival and is associated with resistance to cancer drugs. ${ }^{3,4}$

Gamitrinib-treated tumor cells did not show a compensatory increase in Hsp70.

"The work opens up a new dimension to the Hsp90 field and gives us insights on how to target some diseases and cancers that have not responded to conventional Hsp90 inhibitors," said Thompson. "However, I don't think it takes anything away from current Hsp90 inhibitors that are already in the clinic."

Astex's AT13387, a non-ansamycin inhibitor of Hsp90, is in Phase I testing to treat solid tumors. The company also has an Hsp70 inhibitor program in preclinical development for cancer.

\section{Formal demonstrations desired}

Despite the potential advantages that gamitrinibs offer over conventional Hsp90 inhibitors, researchers contacted by SciBX wanted to see data clearly demonstrating mitochondria-specific Hsp90 inhibition and a series of pharmacokinetic and toxicology studies.

"What they have done is to link an Hsp90 inhibitor backbone to a mitochondrial targeting moiety and assumed that it would target mitochondrial Hsp90," Thompson told SciBX. "But definitive evidence that these compounds are affecting mitochondrial Hsp90 is lacking."

Thompson also said that gamitrinibs are larger than other Hsp90 inhibitors and have charged chemical groups. Those features, he said, "generally come with a number of liabilities including formulation and distribution difficulties that would make it difficult for the molecule to be used as a drug."

Whitesell agreed, adding that gamitrinibs are "apparently still poorly water soluble and had to be formulated in DMSO/Cremophor for administration to animals."

The use of dimethyl sulfoxide (DMSO) in formulating 17-AAG has been implicated as a source of off-target toxicities in clinical trials. ${ }^{5}$ Cremophor-based drug formulations require corticosteroid premedication and have been associated with anaphylaxis, hyperlipidemia, abnormal lipoprotein patterns and neurotoxicity. ${ }^{6}$

Whitesell also wanted to know whether gamitrinibs could have the potential for some mitochondrial toxicity in normal tissues, which may manifest in skeletal muscle or the heart. "Full toxicology across a range of doses and schedules will be essential," he told SciBX. "In addition, considerably more work needs to be done in terms of ADME characterization before one of the compounds described in this manuscript could be advanced as a true clinical candidate."

Finally, he wanted to see a pharmacokinetic study evaluating how stable the linkage between the mitochondrial-targeting and Hsp90inhibiting moieties of the gamitrinibs are in vivo. "17-AAG is rapidly and extensively metabolized by the liver and something similar could happen to the gamitrinibs," he told SciBX. "If such metabolism occurs, the targeted parent compound would disappear very rapidly from the plasma."

Altieri said he is discussing taking the gamitrinibs into clinical development with the National Cancer Institute. His next steps are to conduct long-term efficacy and safety studies in animals.

He said multiple patent applications have been filed covering the structure and biology of the gamitrinibs. The compounds are available for licensing from University of Massachusetts Commercial Ventures and Intellectual Property.

Lou, K.-J. SciBX 2(10); doi:10.1038/scibx.2009.389

Published online March 12, 2009

\section{REFERENCES}

1. Kang, B.H. et al. J. Clin. Invest.; published online Feb. 23, 2009; doi:10.1172/JCl37613

Contact: Dario C. Altieri, University of Massachusetts Medical School, Worcester, Mass.

e-mail: dario.altieri@umassmed.edu

2. Kang, B.H. et al. Cell 131, 257-270 (2007)

3. Whitesell, L. \& Lindquist, S.L. Nat. Rev. Cancer 5, 761-772 (2005)

4. McCollum, A.K. et al. Cancer Res. 68,7419-7427 (2008)

5. Solit, D.B. \& Chiosis, G. Drug Discov. Today 13, 38-43 (2008)

6. Gelderblom, H. et al. Eur. J. Cancer 37, 1590-1598 (2001)

\section{COMPANIES AND INSTITUTIONS MENTIONED}

Astex Therapeutics Ltd., Cambridge, U.K.

Biogen Idec Inc. (NASDAQ:BIIB), Cambridge, Mass.

Bristol-Myers Squibb Co. (NYSE:BMY), New York, N.Y.

Infinity Pharmaceuticals Inc. (NASDAQ:INFI), Cambridge, Mass.

National Cancer Institute, Bethesda, Md.

Novartis AG (NYSE:NVS; SIX:NOVN), Basel, Switzerland

University of Massachusetts Medical School, Worcester, Mass.

Vernalis plc (LSE:VER), Winnersh, U.K.

Whitehead Institute for Biomedical Research, Cambridge, Mass. 